Images in...

\title{
Whirl sign in small bowel volvulus
}

\author{
Yu Min Huang, ${ }^{1}$ Chin Chia Jimmy $\mathrm{Wu}^{2}$ \\ ${ }^{1}$ Division of General Surgery, Department of Surgery, Buddhist Tzu Chi General Hospital, Hualien, Taiwan \\ ${ }^{2}$ Division of Colorectal Surgery, Department of Surgery, Buddhist Tzu Chi General Hospital, Hualien, Taiwan
}

Correspondence to Dr Chin Chia Jimmy Wu, wccstillthought@yahoo.com.tw

\section{DESCRIPTION}

A 43-year-old man without previous abdominal operations came to the hospital due to sudden onset abdominal pain and vomiting. His abdomen was soft. Laboratory data confirmed leukocytosis and severe acidosis ( $\mathrm{pH}$ 7.16). Abdominal CT revealed a twist of mesentery around the axis of the superior mesenteric artery (figure 1) and poor contrast-enhanced bowel loops (figure 2). Emergent laparotomy showed that the small bowel volvulus had caused bowel necrosis. No malrotation or adhesions were seen. A segmental bowel resection was performed; the patient recovered and was discharged on postoperative day 16 .

Small bowel volvulus has been responsible for $1.7 \%$ of all intestinal obstructions and is classified into two types. The primary type occurs in an otherwise normal abdominal cavity and is rare in adults, accounting for $10-22 \%$ of small bowel volvulus in Western countries, and $30 \%$ in Africa and the Middle East. ${ }^{1}$ The secondary type occurs in the presence of a pre-existing lesion, such as an adhesive band or malrotation.

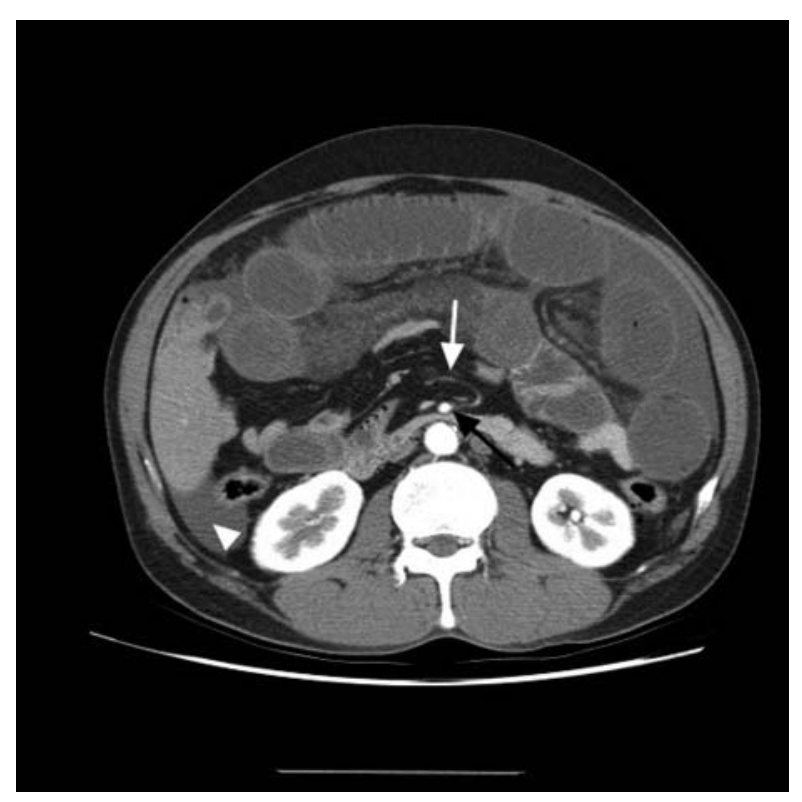

Figure 1 CT scan of the abdomen with intravenous contrast showed bowel swelling. Small bowel mesentery showed a counterclockwise whirl-like pattern (white arrow) around the axis of the superior mesenteric artery (black arrow). A moderate amount of ascites can be seen in the peritoneal cavity (white arrowhead).

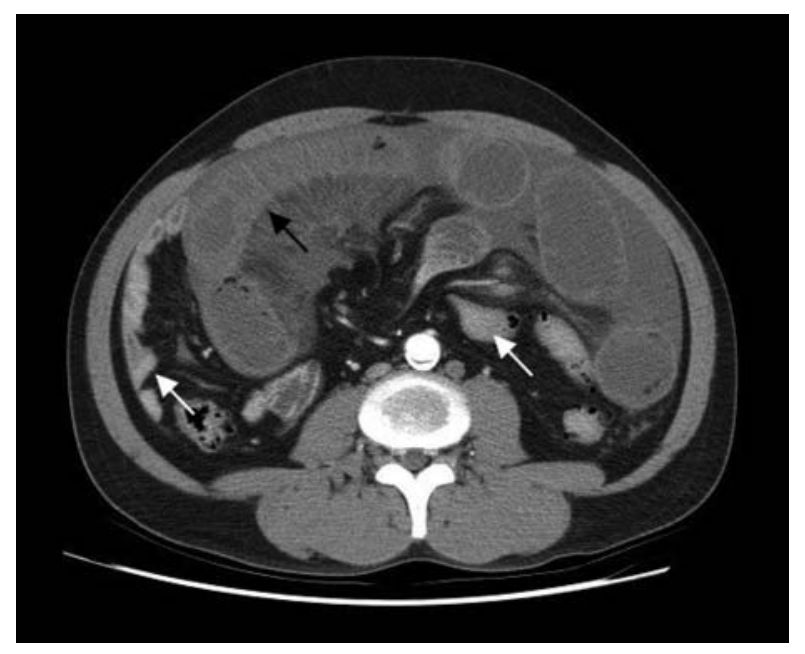

Figure 2 In comparison with the collapsed bowel loops with contrast enhancement (white arrows), the dilated bowel loops without contrast enhancement (black arrow), are dark on the image.

A 'whirlpool sign' in colour Doppler sonography signals the superior mesenteric vein and mesentery have wrapped around the superior mesenteric artery. The sensitivity and specificity of the 'whirlpool sign' for midgut volvulus caused by malrotation are $92 \%$ and $100 \%$, respectively. ${ }^{2}$ However, sonography is operator dependent. The CT 'whirl sign' has shown a sensitivity of $60 \%$ and a specificity of $94 \%$. The OR for the 'whirl sign' predicting a small bowel obstruction necessitating surgery was 25.3. ${ }^{3}$ Both the 'whirl sign' in CT and the 'whirlpool sign' in sonography indicate early surgical intervention.

\section{Learning points}

- Keep in mind that small bowel volvulus is a rare but severe condition.

- The 'whirl sign' and poor contrast-enhanced bowel loops under enhanced abdominal CT indicate a greater necessity for early surgical intervention.

Competing interests None.

Patient consent Obtained. 


\section{BMJ Case Reports}

\section{REFERENCES}

1. Anton R, Leslie WO. Acute small bowel volvulus in adults: sporadic form of strangulating intestinal obstruction. Ann Surg 1992;216:135-41.
2. Shimanuki Y, Aihara T, Takano $\mathrm{H}$, et al. Clockwise whirlpool sign at color Doppler US: an objective and definite sign of midgut volvulus. Radiology 1996;199:261-4.

3. Duda JB, Bhatt $S$, Dogra VS. Utility of CT whirl sign in guiding management of small-bowel obstruction. AJR Am J Roentgenol 2008;191:743-7.

This pdf has been created automatically from the final edited text and images.

Copyright 2012 BMJ Publishing Group. All rights reserved. For permission to reuse any of this content visit http://group.bmj.com/group/rights-licensing/permissions.

BMJ Case Report Fellows may re-use this article for personal use and teaching without any further permission.

Please cite this article as follows (you will need to access the article online to obtain the date of publication).

Huang YM, Wu CCJ. Whirl sign in small bowel volvulus. BMJ Case Reports 2012;10.1136/bcr-2012-006688, Published XXX

Become a Fellow of BMJ Case Reports today and you can:

- Submit as many cases as you like

- Enjoy fast sympathetic peer review and rapid publication of accepted articles

- Access all the published articles

- Re-use any of the published material for personal use and teaching without further permission

For information on Institutional Fellowships contact consortiasales@bmjgroup.com

Visit casereports.bmj.com for more articles like this and to become a Fellow 